\title{
The Importance of Awareness of Heritage Building's Seismic Behaviors: Specific on Pagoda-Type Structure
}

\author{
I. P. Ellsa Sarassantika ${ }^{1, a)}$ \& Ida Bagus Gede Parama Putra ${ }^{2, b)}$ \\ ${ }^{1)}$ Civil Engineering, National Central University, Taiwan. \\ ${ }^{2)}$ Civil Engineering, Universitas Warmadewa. \\ Correspondent : ${ }^{a}$ ellsa.sarassantika@warmadewa.ac.id \& ${ }^{b}$ Parama.putra91@gmail.com
}

\begin{abstract}
The importance of building cultural heritage. A place where historical stories, cultural values, places of worship, symbols of struggle and even now are transformed into tourist attractions and educational facilities. Keeping this building good and well maintained is a good thing to do. The purpose of this paper is to enhance awareness of the importance of knowledge about heritage buildings from the viewpoint of building structure and seismicity. In addition, as a research initiation on the performance of the existing pagoda structure in Bali, Meru, going forward. This paper reviews several studies of pagodas in numerous countries, both in terms of structural design, influence and structure on earthquake response, damage, and handling in terms of reinforcement and maintenance. Comprehensively summarizes the studies that have been done, this facilitates understanding of existing studies. With the hope of being able, to trigger and encourage studies on building cultural heritage in Indonesia in general and Bali in particular. Research on the pagoda in Bali in the future is highly expected and needs to be done.
\end{abstract}

Keyword : infrastructure management, heritage structure, meru; Balinese pagoda, earthquake responses

\section{INTRODUCTION}

Cultural heritage buildings are spread in each country with its own uniqueness. This building keeps history from the surrounding community since the era where the building was built. Sometimes this building also becomes a symbol of the journey and struggle of the surrounding community. Apart from being a symbol, some traditional buildings have also become places of worship (such as temples) of the surrounding community, and it continues to this day. Not only judging from its historical function and usage, this traditional old building is also equipped with an architectural design that attracts attention, so it can be a great place to visit. Therefore, it is common for the cultural heritage building to become a place for educational facilities, both local and international communities. In fact, not a few of them have been registered in the "world cultural heritage" as a form of appreciation and increase public awareness of the importance of the cultural heritage.

In terms of preserving cultural heritage, not just talking about the influence of behavior from the surrounding community. Major influences also come from the surrounding natural behavior, such as weather and natural disasters. Strength and behavior of cultural heritage structures are tested as time goes by. Damage sometimes occurs. This is where the important role of public awareness in maintaining, can be in the form of preventive efforts, maintenance, and repairs of the effects caused by natural catastrophes.

The heritage building is an important infrastructure asset for the nation or region. It must be well managed in order to be always in good condition, in accordance to the Principal of 
Infrastructure Asset Management (Suprayitno \& Soemitro, 2018). Therefore, awareness to the risk to the seismic must be well developed.

In some countries, earthquakes pose a major threat to not only buildings but also those around them. In the case of buildings, several aspects of the building structure and structure itself influence the response of buildings to earthquakes. The influence of the type and nature of building materials, the dimensions of the constituent elements, and the configuration of the composition of the elements and their connectors. This provides a wide and varied response to earthquakes, especially in older buildings of cultural heritage, which has unique and unusual shapes, unlike today's buildings whose construction codes use design instructions. Hence, research regarding the behavior of cultural heritage building structures is something that is needed in each region. Not only buildings that have the potential to be damaged by disaster, but also buildings that are intact after a disaster can also provide good knowledge for us. So that it can be understood how to maintain, repair, strengthen, and build better cultural heritage buildings going forward.

Some research on building cultural heritage (especially pagodas) in Japan, China, and Nepal, learn about the performance of buildings in earthquakes from several aspects namely material, structure, soil type and ultimate capacity, even the potential for damage and antiearthquake capability that has not been revealed from the ancient building.

From the literature mentioned above, it is known the usefulness of the importance of learning about the structural performance of buildings, from both material adjustment, structure monitoring, repair and strengthening techniques if needed, developing simulation analyzes with validation experiments and even providing suggestions for assessing the feasibility of postearthquake buildings. This also concludes that this kind of pagoda building is a special attraction for engineers to study (Endo \& Hanazato, 2018; Hanazato, Fujita, \& Sakamoto, 2004; Nakahara, Hisatoku, \& Nagase, 2000; Sonda et al., 2017; Toshikazu, Chikahiro, \& Yasushi, 2010; Yuan \& Li, 2001).

In Indonesia, many researchers who examine the structure of this kind of pagoda, especially Balinese architecture that focuses on "Meru". A lot of literature that discusses the types and distribution of this Meru (Paramadhyaksa, 2010), the philosophical meaning of its form (Paramadhyaksa, 2016; William et al., 2017) and its uses including its 3D design ratio (Gunawarman, 2016). However, there has not much literature and it is even difficult to find a discussion about the importance of the earthquake aspect of Meru.

Therefore, this paper intends to discuss the importance of awareness about cultural heritage buildings, especially buildings that resemble pagodas, by reviewing some previous studies and concluding research that needs to be done on cultural buildings in Indonesia in general, especially on Meru in Bali. With hope for the future, this paper can be a trigger for the development of learning about other aspects of seismicity from Meru. So that in the end, people get more knowledge about how to better protect cultural heritage buildings. Moreover, this study will support government concern about asset management especially in tourism infrastructure or curtural asset according to the guidelines, UU RI Nomor 11 Tahun 2010 regarding Curtural Heritage, and Peraturan Daerah Provinsi Bali Nomor 4 Tahun 2014 regarding preserving Bali's cultural heritage. In which the derivation of this guidelines are various program to maintain this asset in good condition. For example in article 53, and article 57, preservation is based on the results of feasibility studies that can be accounted for academically, technically, and administratively. Furthermore must be carried out or coordinated by Conservation Experts with due regard for the ethics of preservation for any urget situation, for example natural disaster like earthquakes. 


\section{RESEARCH METHOD}

This paper reviews several studies of pagodas in different places and in different years of built. Summarize some aspects of the pagoda building such as the constituent materials of the pagoda, the shape of the structure, and the uniqueness of the behavior of each structure. Moreover, of course, reveal details of damages suffered due to the behavior of the structure.

Not only discussing each existing structure and damages, in this paper also reveals some improvements and structural adjustments made to the damages that have occurred. This paper also discussed some additional treatments that may assist in the maintenance of this heritage building structure. By seeing in detail what is experienced by existing heritage buildings. This can be a valuable learning material for reference on how to maintain other cultural heritages, such as the pagoda type building in Bali, Meru.

\section{DATA COLLECTION}

There are many pagoda type buildings spreads throughout the world. Several ancient pagoda buildings with similar types that have been comprehensively studied can represent it. To make it easier to learn, take several studies of pagodas in China, namely Sakyamuni Pagoda of Fogong Temple and Hebai, Dingxian, pagoda lookout. Also in the review are some of the pagodas in Japan namely, Horyuji Temple and Eimyou-in Goju-no-to. As a comparison also discussed some of the events that exist in Nepal, precisely at the pagoda in Radha Krishna Temple and Hirnya Varna Mahavihar. The review focuses on the upper structure. The lower part such as discussion of the foundation and soil type will be discussed later in another paper. Here are some of the history of the pagoda's pagoda that will be discussed.

\section{Sakyamuni Pagoda of Fogong Temple}

Built in A.D. 1056 in Yinxian county Shanxi province. Nearly thousands of years old, this pagoda has experienced many earthquakes. This building is a symbol of an ancient city or a very beautiful place, and has important cultural values in Chinese history (Yuan \& Li, 2001).

\section{Hebai, Dingxian, lookout pagoda.}

With the development of ancient construction technology, ancient Chinese workers gradually chose to constructs pagoda with brick and stone instead of using wood. Excellent in terms of fire resistance and weathering resistance, so the pagoda can last longer. This pagoda was built on A.D. 1005. This pagoda has experienced damage to the roof due to the earthquake (Yuan \& Li, 2001).

\section{Pagoda of Horyuji Temple}

Introduced at the same time as Buddhism came from India through China around the middle of the 6th century. Over the ensuing years, around 1300 years, many pagodas faced several largescale earthquakes, without significant damage. The Pagoda of Horyuji Temple is the oldest wooden pagoda in Japan. Many researchers are studying how this type of Pagoda can survive well during an earthquake (Nakahara et al., 2000).

\section{Eimyou-in Goju-no-to.}

Designed by today's engineers to follow the type that existed in the Edo era (during the 17th century and 18th century) is one of the smaller pagodas in Japan. Located in Himi-City, Toyama Prefecture in Japan in 2002 (Hanazato et al., 2004).

\section{Pagoda in Radha Krishna Tempel}

Built in the middle of the 17th century, this pagoda was hit by a serious earthquake in Nepal in 1988. The second level of the total three levels of this pagoda collapsed and then repaired in 
1992. Repairs are intended to strengthen this Pagoda, but in 2015, the whole structure of this pagoda collapsed due to the earthquake (Endo \& Hanazato, 2018).

\section{Hirnya Varna Mahavihar Pagoda}

Buddhist monastery in Lalitpur, Kathmandu Valley, Nepal.built in the 12th century. The renovation of this religious building began in 2008 and was completed in 2012 with assistance from SCAEF, the society of consulting architectural and engineering firm in Nepal. This building survived a major earthquake in 2015 with minimal damage (Sonda et al., 2017). Discussion through comparison of these pagodas can show in Table 1. 


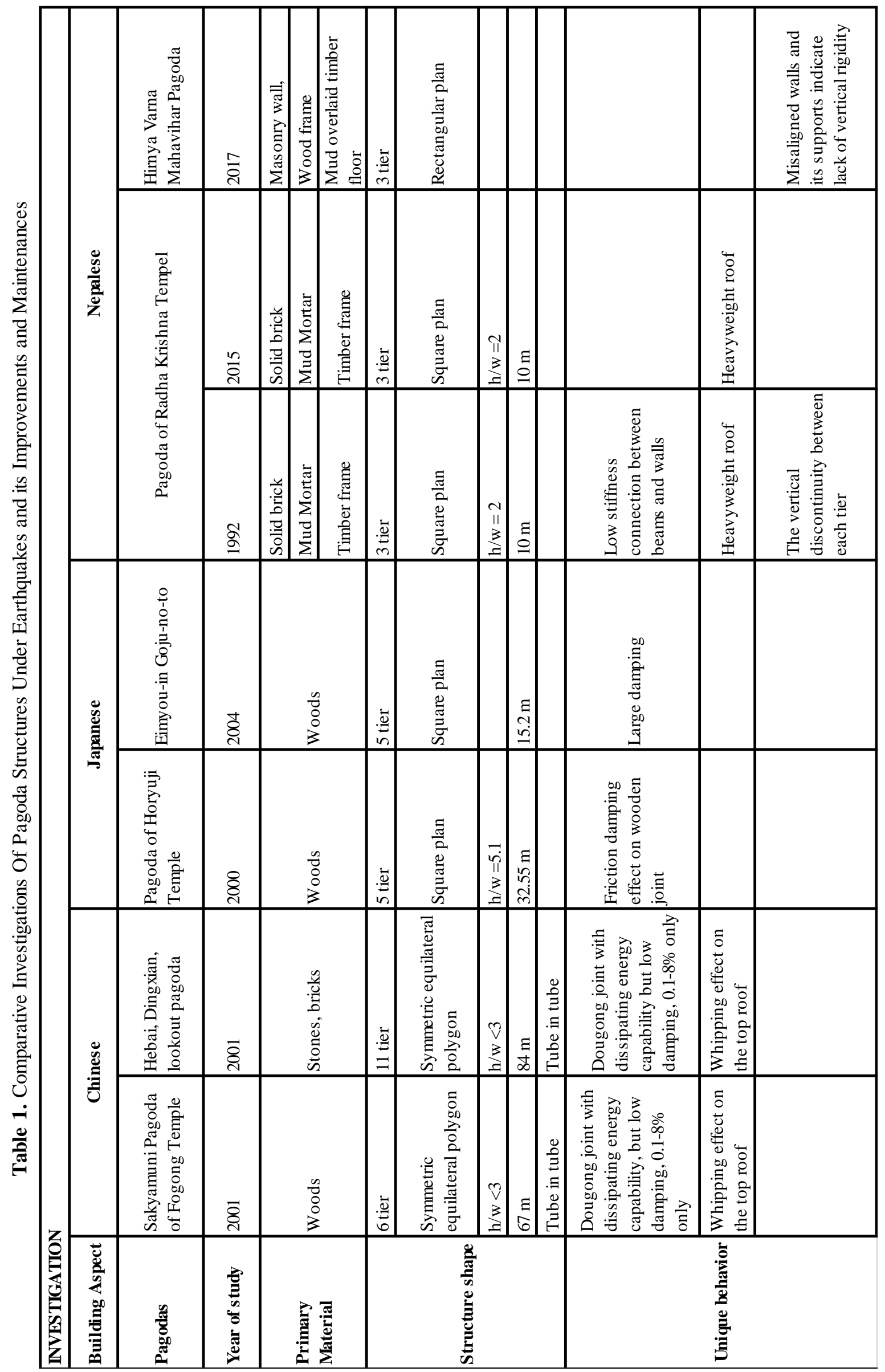


(e)ISSN 2656-8896 (p)ISSN 2656-890X

Journal of Infrastructure and Facility Asset Management - Vol. 2, Issue. 1, March 2020

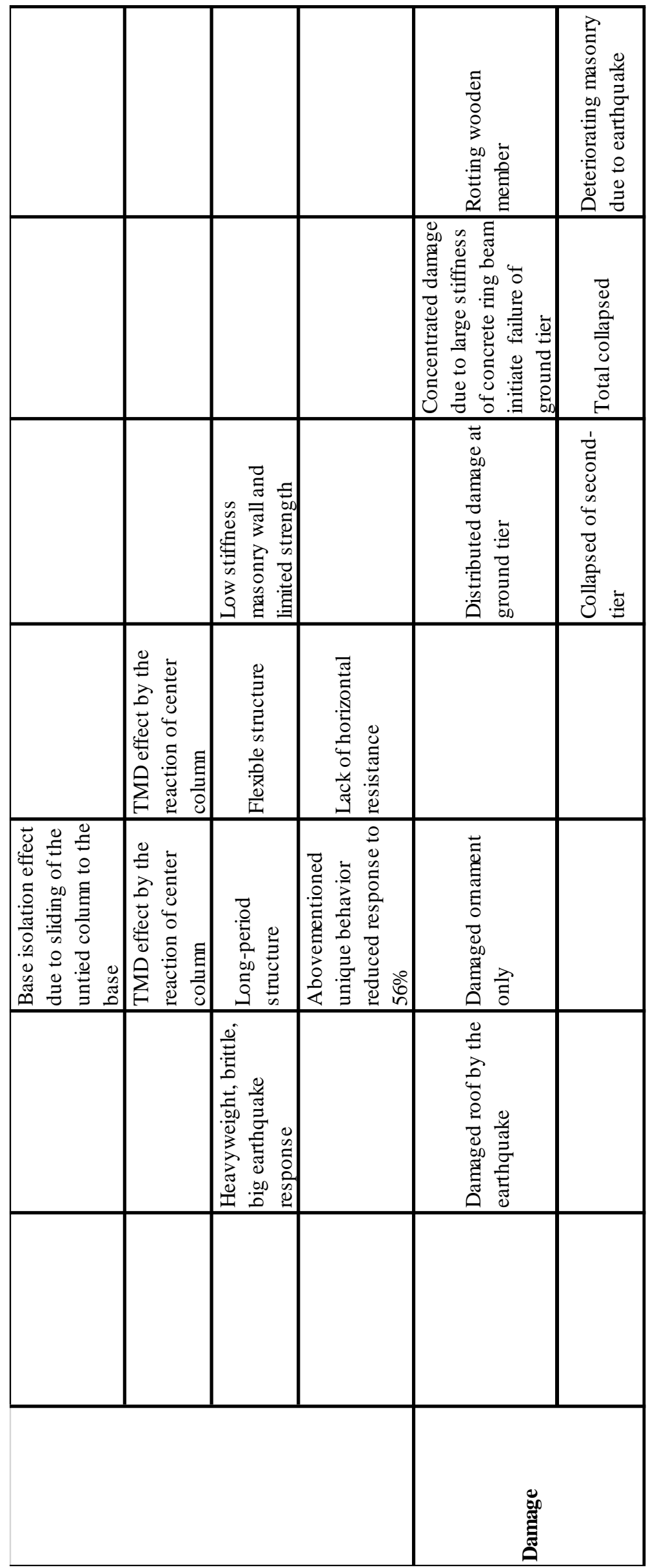




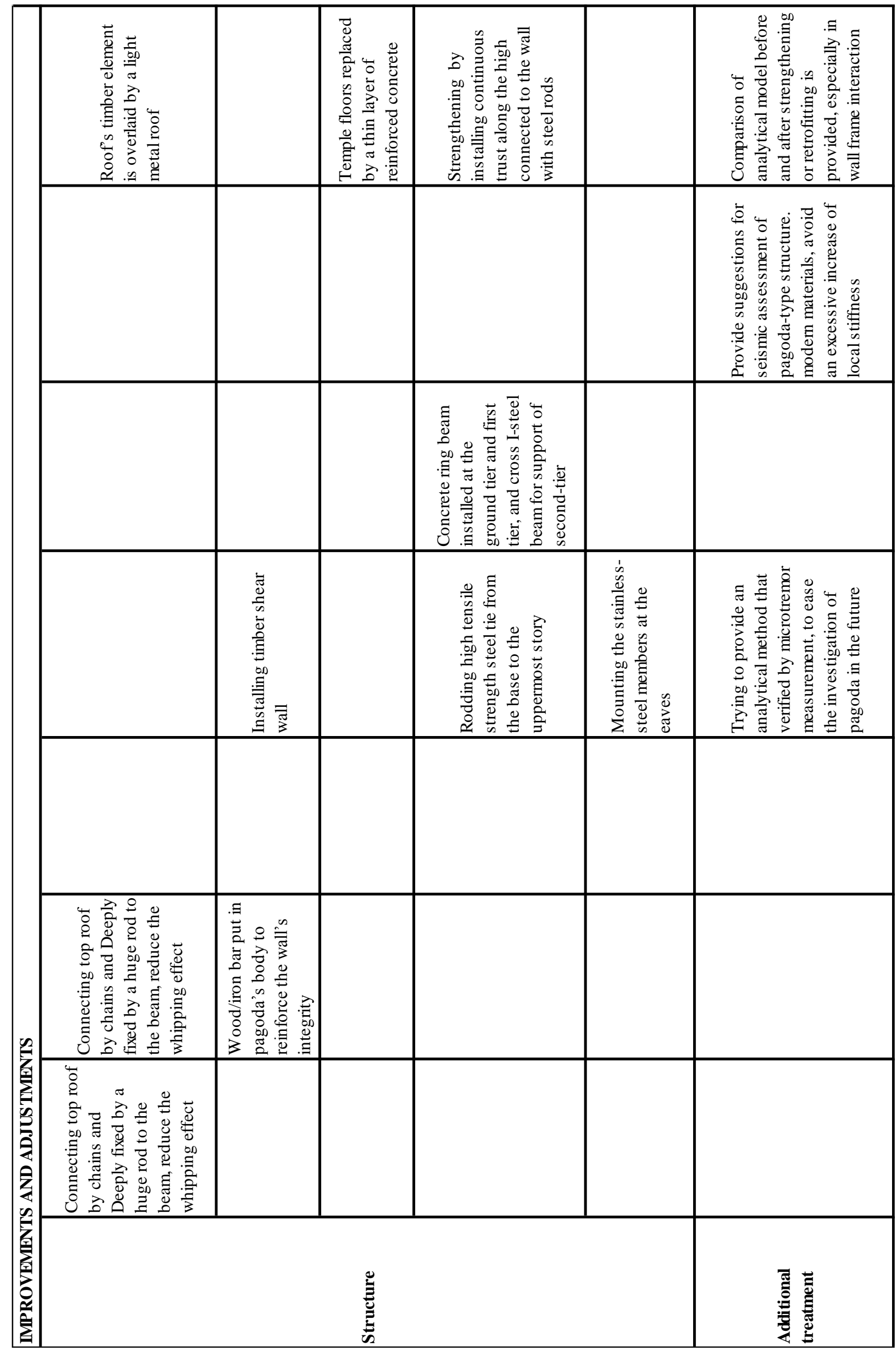


When compared with existing pagoda buildings in Bali, Meru, the similarity in structure and construction technology can be discovered. First introduced in Bali by a priest in the 11th century. With many variations of Meru from the number of levels namely, 3, 5, 7, 9 and even 11 levels (Paramadhyaksa, 2010). Although it has similar structural shapes, the structural performance is not necessarily the same, this is proven by several examples that have been described previously. Therefore, in maintaining and preserving this cultural heritage building, a special study on Meru seismic performance is needed.

\section{RESULTS AND DISCUSSION}

Variations in performance can be related to maintenance, structural completeness, and structure size. One of the main reasons for the poor performance of the pagoda structure is the lack of maintenance and obsolescence due to age, harsh climatic conditions. The performance of pagoda structures varies widely from one case to another, even in the presence of the same construction material, and the similar architectural feature.

Differences in structural dimensions and construction details can cause significant differences in seismic performance. It can be viewed on the variation of the connection, ranging from which has a low stiffness varied to good attenuation against earthquakes. The weight of buildings that can respond to earthquakes varies. The combination of weight and stiffness that varies can be transformed into a flexible or rigid structure, where the response to the earthquake to be different. The weight distribution in the structure is also important to note due to the whipping effect on the roof. The continuity of the vertical structure stiffness must also be considered since this is one reason how a building can still stand intact. Every detail must be studied because the level of damage can be spread from local mechanisms to structure global failure.

The uniqueness of the structure has its own damage model and has its individual maintenance requirement. Furthermore, the construction design of each building of diverse cultural heritage must be studied specifically, so that the handling in maintenance is also appropriate and efficient. Generalization of pagoda handling can lead to damage to buildings.

Another thing to be noted is that some construction details on the pagoda can also be designed with output effects that can reduce earthquake response such as; the base isolation effect, TMD effect, silencer effect.

Investigation and analysis of dynamic features and behavior in seismicity can provide a reference in assessing post-earthquake structures including repairs and reinforcement of structures.

\section{CONCLUSIONS}

Based on the studies that have been done by previous researchers about the pagoda, the studies conducted can be taken into consideration in maintaining the existing cultural heritage. This can also be used as the first step in research to find out how to maintain existing cultural heritage buildings in Bali, especially Meru.

ACKNOWLEDGMENT. The author wishes to thanks all of academics in Department of Architecture at Warmadewa University for their help to conduct the present study. The funding from Warmadewa University supports this paper.

\section{BIBLIOGRAPHY}

Endo, Y. \& Hanazato, T. (2018). "Seismic Analysis of a Three-Tiered Pagoda Temple Affected by the 2015 Seismic Analysis of a Three-Tiered Pagoda Temple Affected by the 2015 Gorkha Earthquake". International Journal of Architectural Heritage, 1-14. https://doi.org/10.1080/15583058.2018.1550534 
Gunawarman, R. (2016). “Teknologi Bangunan Tradisional Meru Tumpang Lima Pura Puseh dan Beji Desa Adat Seminyak". UNDAGI Jurnal Arsitektur Warmadewa, Vol 4, 58-62

Hanazato, T., Fujita, K. \& Sakamoto, I. (2004). "Analysis of Earthquake Resistance of FiveStoried Timber Pagoda". 13 Th World Conference on Earthquake Engineering, (1223), 79-95.

Nakahara, K., Hisatoku, T. \& Nagase, T. (2000). "Earthquake Response of Ancient Five-Story Pagoda Structure of Horyu-Ji Temple in Japan". 12 Th World Conference on Earthquake Engineering, (1229), 1-6.

Paramadhyaksa, I. N. W. (2010). "Makna filosofis keberadaan ornamen Bedawang Nala di Dasar Bangunan Meru”. Filsafat, 20(1), 45-55. https://doi.org/https://doi.org/10.22146/ jf.3432

Paramadhyaksa, I. N. W. (2016). "Konsepsi Panca Mahabhuta dalam Perwujudan Arsitektur Tradisional Bali", Jurnal ArchiGreen Vol. 3 No. 5 (2016) 1-14.

PerdaProvBali 4/14. Peraturan Daerah Provinsi Bali Nomor 4 Tahun 2014 tentang Pelestarian Warisan Budaya Bali.

Sonda, D., Bothara, J., Chesi, C., Sumini, V., Tonna, S., \& Planas, B. (2017). "Analysis of the Seismic Performance of a Strengthened Pagoda Temple during Gorkha Earthquake”. 16 The World Conference on Earthquake Engineering, (4232).

Suprayitno, H. \& Soemitro, R.A.A. (2018). "Preliminary Reflexion on Basic Principle of Infrastructure Asset Management". Jurnal Manajemen Aset Infrastruktur \& Fasilitas, Vol. 2, No. 1, Maret 2018, Hal. : 1-10.

Toshikazu, H., Chikahiro, M., \& Yasushi, N. (2010). "Seismic and Wind Performance of FiveStoried Pagoda of Timber Heritage Structure". Advanced Materials Research, 134, 7995. https://doi.org/10.4028/www.scientific.net/AMR.133-134.79

UU 11/10. Undang-Undang Republik Indonesia Nomor 11 Tahun 2010 tentang Cagar Budaya. William, R., \& Yuswadi, I., (2017). "The Architecture of Pagodas Viewed from the Angle of Site Lay-Out, Proportion, and Symbolization", Jurnal Riset Arsitektur Vol 1, (2), April 2017; 192-208.

Yuan, J., \& Li, S. (2001). "Analysis and Investigation of Seismic Behavior for MultistoryPavilion Ancient Pagodas in China". Transactions on the Built Environment, 55. 
(e)ISSN 2656-8896 (p)ISSN 2656-890X

Journal of Infrastructure and Facility Asset Management - Vol. 2, Issue. 1, March 2020 